\title{
PREDIKSI KEBANGKRUTAN PADA BANK BUMN YANG TERDAFTAR DI BURSA EFEK INDONESIA
}

\author{
Muhammad Salman 1)*, Catur Wulandari 1) \\ ${ }^{1 *}$ Fakultas Ekonomi, Universitas Samudra \\ *Penulis Korespondensi: muhammadsalman@unsam.ac.id, caturwulandari34@gmail.com
}

\begin{abstract}
The research was conducted with the aim of knowing the prediction of the potential for bankruptcy of the four State-Owned Enterprises (BRI, BNI, Bank Mandiri and BTN) using the Altman Z-Score, Springate and Grover $G$-Score models. The data analysis method used a prediction model for the occurrence of bankruptcy consisting of the Altman Z-Score, Springate and Grover G-Score. The results showed that the prediction of bankruptcy (financial distress) using the Altman Z Score model was obtained from 2015-2019 for the four State-Owned Enterprise Banks (BRI, BNI, Bank Mandiri and BTN) as a whole obtained Z Score between 1.42-1 88 or at the criteria (cut off) $Z<181$ has the potential to go bankrupt and $1.81<Z<2.99$ gray area. Meanwhile, based on the Springate model from 2015-2019, the four State-Owned Enterprises (BRI, BNI, Bank Mandiri and BTN) overall obtained a Springate of 1.95 - 44.08 and were in the criteria (cut off) $S>0.862$ and can be declared as not potentially bankrupt (healthy). Then based on Grover, it was obtained from 2015-2019 in the four State-Owned Enterprise Banks (BRI, BNI, Bank Mandiri and BTN) as a whole obtained a G Score of $1.71-2.15$ and were in the criteria of $G \geq 0.01$ or no potential bankrupt (healthy). The results showed that the Altman $Z$ Score model has a better value than Springate and Grover because the number of ratios is more so that it can predict bankruptcy better
\end{abstract}

Keywords: Altman Z-Score, Springate, Grover G-Score, Financial Distress

Informasi Artikel:

Artikel Diterima: 18 Februari 2021

Artikel Direvisi: 28 Februari 2021

Artikel Disetujui: 22 Maret 2021 


\section{PENDAHULUAN}

Bank memiliki peranan penting dalam pembangunan ekonomi suatu negara. Bank pada umumnya memiliki dua tujuan, yaitu meyediakan mekanisme dan alat pembayaran yang efisien dan praktis bagi nasabah dan menerima tabungan dari nasabah kemudian menyalurkan tabungan nasabah dalam bentuk pinjaman kepada pihak yang membutuhkan dana atau dalam arti lain meningkatkan arus dana untuk investasi dan aktivitas produktif sehingga menghasilkan laba. Laba yang diperoleh perusahaan secara umum berdasarkan hasil operasionalnya (Zulkarnain, 2020). Operasional perusahaan dapat berjalan lancar karena adanya modal yang dimiliki dan modal ini salah satunya bersumber dari investasi. Investasi yang diperoleh dari investor, dimana investor akan tertarik berinvestasi bila perusahaan dalam kondisi sehat atau tidak berpotensi bangkrut.

Bank umum Badan Usaha Milik Negara juga dikenal sebagai bank persero yang sebagian atau seluruh sahamnya dimiliki oleh pemerintah. Ada empat bank umum Badan Usaha Milik Negara di Indonesia yaitu Bank Negara Indonesia, Bank Rakyat Indonesia, Bank Mandiri dan Bank Tabungan Negara. Sebagai bank Badan Usaha Milik Negara tentunya harus menjaga kondisi usaha bank agar tidak mengalami kesulitan keuangan yang dapat mengganggu operasional bank. Kondisi kebangkrutan (financial distress) dapat terjadi karena adanya kelemahan dari industri perbankan.)Berbagai kelemahan yang ada dalam industri perbankan antara lain, lemahnya manajemen bank, konsentrasi kredit yang berlebihan, kecurangan, terbatas dan kurangnya transaparansi informasi kondisi keuangan bank dan belum efektifnya pengawasan Bank Indonesia.(Rahmat, 2005)

Resiko kebangkrutan dapat dihindari dengan melihat kondisi perusahaan di bagian keuangan. Selain itu, dengan analisis tingkat kesehatan keuangan, juga akan dapat dinilai kemampuan perusahaan untuk memenuhi kewajiban jangka pendek, struktur modal perusahaan, distribusi aktiva, keefektifan penggunaan aktiva, hasil usaha atau pendapatan yang telah dicapai, beban tetap yang harus di bayar serta memprediksi seberapa besar resiko kebangkrutan yang mungkin akan dialami perusahaan.

Apabila suatu perusahaan telah bangkrut, berarti perusahaan tersebut mengalami kegagalan. Oleh karena itu, perusahaan sedini mungkin harus melakukan berbagai analisis terutama analisis kebangkrutan untuk memperoleh peringatan awal adanya tandatanda kebangkrutan. Semakin awal tanda kebangkrutan tersebut diketahui, maka semakin baik bagi pihak manajemen untuk bisa melakukan perbaikan-perbaikan. Pihak kreditur dan juga pihak pemegang saham dapat melakukan persiapan untuk mengatasi berbagai kemungkinan yang buruk terjadi pada perusahaan.

Kondisi tanda-tanda perusahaan mengalami financial distress adalah kondisi dimana perusahaan mengalami laba bersih operasi negatif selama beberapa tahun dan selama lebih dari satu tahun tidak melakukan 
pembayaran dividen, pemberhentian tenaga kerja atau menghilangkan pembayaran dividen (Whitaker dalam Rahayu, 2016). Platt (2002), menyatakan bahwa untuk mengatasi dan meminimalisir terjadinya financial distress perusahaan dapat mengawasi kondisi keuangan dari segi neraca dan laporan laba rugi yang ada dalam laporan keuangan dengan menggunakan teknik-teknik analisis laporan keuangan. Kondisi financial distress dapat dikenali lebih awal sebelum terjadinya dengan menggunakan suatu model peringatan dini (early warning system). Model ini dapat digunakan sebagai alat untuk mengenali gejala awal kondisi financial distress.

Secara empiris, kebangkrutan atau likuidasi akibat financial distress dapat dibuktikan sebagaimana yang telah dilakukan oleh beberapa peneliti dengan menggunakan rasio keuangan. Analisis financial distress yang sering digunakan yaitu model Altman (Zscores), model Springate (S-score) dan model Zmijewski (X-score).

Penelitian mengenai financial distress telah banyak dilakukan, sehingga memunculkan berbagai model prediksi kebangkrutan yang digunakan sebagai alat untuk memperbaiki kondisi perusahaan. Adhitya, dkk (2014), melakukan penelitian mengenai analisis potensi kebangkrutan dengan menggunakan model Altman Z score, Springate dan Zmijewski pada industri perdagangan ritel yang terdaftar di BEI periode 2009-2013. Hasil penelitian menunjukkan bahwa model springate yang lebih akurat dibandingkan Altman Z score dan Zmijewski dengan menghitung standar deviasinya. Selanjutnya Prihanthini dan Maria (2013), melakukan penelitian mengenai analisis prediksi kebangkrutan dengan model Altman Z score, Springate dan Zmijewski pada perusahaan manufaktur sektor food beverage. Hasil penelitian menunjukkan bahwa terdapat perbedaan yang signifikan dalam memprediksi kebangkrutan untuk setiap model dan model altman $\mathrm{Z}$ score merupakan model prediksi yang paling sesuai diterapkan di perusahaan food and beverage tersebut. Kebangkrutan pada perusahaan perbankan dan termasuk dalam hal ini pada Bank BUMN dapat terjadi karena salah satunya berupa pendapatan dan laba besih. Pendapatan dan laba bersih menjadi salah satu sumber keuangan pada perusahaan. Karena dengan sedikitnya perolehan pendapatan dan laba bersih akan memberikan gambaran bagi investor untuk menanamkan modal pada perusahaan. Semakin sedikit yang mau berinvestasi maka sedikit pula permodalan pada perusahaan. Pada tabel 1 dapat diketahui perolehan pendapatan dan laba bersih pada Bank BUMN yang terdaftar di BEI tahun 2016 dan 2019 pada tabel 1. 
Tabel 1 Pendapatan dan Laba Bersih yang Terdaftar di BEI Tahun 2016-2019

\begin{tabular}{|c|c|c|c|c|c|c|c|c|c|}
\hline \multirow[t]{2}{*}{ No } & \multirow[t]{2}{*}{$\begin{array}{c}\text { Nama } \\
\text { Perusahaan }\end{array}$} & \multicolumn{4}{|c|}{$\begin{array}{l}\text { Pendapatan } \\
\text { (Rp triliun) }\end{array}$} & \multicolumn{4}{|c|}{$\begin{array}{c}\text { Laba Bersih } \\
\text { (Rp triliun) }\end{array}$} \\
\hline & & 2016 & 2017 & 2018 & 2019 & 2016 & 2017 & 2018 & 2019 \\
\hline 1 & $\begin{array}{l}\text { PT. Bank } \\
\text { Rakyat } \\
\text { Indonesia } \\
\text { (Persero) } \\
\text { Tbk }\end{array}$ & 70,80 & 77,30 & 111,58 & 121,75 & 41,34 & 30,80 & 28,91 & 39,40 \\
\hline 2 & $\begin{array}{l}\text { PT. Bank } \\
\text { Negara } \\
\text { Indonesia } \\
\text { (Persero) } \\
\text { Tbk }\end{array}$ & 43,76 & 48,17 & 54,13 & 22,17 & 11,41 & 13,77 & 15,01 & 15,38 \\
\hline 3 & $\begin{array}{l}\text { PT. Mandiri } \\
\text { (Persero) } \\
\text { Tbk }\end{array}$ & 76,70 & 79,50 & 80,99 & 91,52 & 40,34 & 23,32 & 23,77 & 34,65 \\
\hline 4 & $\begin{array}{l}\text { PT. Bank } \\
\text { Tabungan } \\
\text { Negara } \\
\text { (Persero) } \\
\text { Tbk }\end{array}$ & 17,13 & 19,27 & 22,85 & 25,71 & 2,61 & 3,02 & 2.78 & 0,55 \\
\hline
\end{tabular}

Sumber: www.idx.co.id

Berdasarkan data tabel 1 dapat dilihat kondisi dari Bank BUMN tahun 2016 sampai tahun 2019 berdasarkan pendapatan Bank Rakyat Indonesia cenderung meningkat. Sementara Bank Negara Indonesia juga terjadi peningkatan pendapatan dari tahun 2016 dan tahun 2018 tetapi pada tahun 2019 mengalami penurun dimana pada tahun 2018 sebesar Rp 77,30 triliun menjadi $\mathrm{Rp} 22,17$ triliun. Kemudian pada Bank Mandiri pendapatan pendapatan dari tahun 2016 sampai dengan tahun 2019 mengalami peningkatan dan pada Bank Tabungan Negara pendapatan juga mengalami peningkatan dari tahun 2016 sampai dengan tahun 2019. Sementara laba bersih pada PT. Bank Rakyat Indonesia (Persero) Tbk 2017 dan tahun 2018 mengalami penurunan, pada PT. Bank Negara Indonesia (Persero) Tbk laba bersih yang diperoleh pendapatan yang diperoleh tahun 2019 mengalami penurunan. Pada PT. Bank Mandiri
(Persero) Tbk perolehan laba bersih mengalami penurunan di tahun 2017 dan tahun 2018. Sementara pada PT. Bank Tabungan Negara (Persero) Tbk di tahun 2016 sampai tahun 2018 mengalami peningkatan tetapi di tahun 2019 perolehan laba bersih mengalami penurunan menjadi hanya 0,55 triliun.

Pendapatan dan laba bersih sebagai bagian dari pengukur kondisi financial distress menunjukkan pendapatan di tahun 2019 dan perolehan laba bersih pada PT. Bank Rakyat Indonesia (Persero) Tbk tahun 2018 serta pada PT. Bank Tabungan Negara di tahun 2019 yang memberikan gambaran bahwa menurunnya pendapatan dan laba bersih dapat mengindikasikan kesulitan keuangan. Hal tersebut karena semakin sedikit pendapatan atau laba yang diperoleh akan berdampak pada kondisi keuangan perbankan. Kesulitan keuangan apabila berkelanjutan akan berdampak pada kebangkrutan perusahaan perbankan.

\section{TINJAUAN PUSTAKA}

Menurut Kasmir (2011), Bank adalah lembaga keuangan yang kegiatan utamanya adalah menghimpun dana dari masyarakat dan menyalurkannya kembali dana tersebut ke masyarakat serta memberikan jasa bank lainnya. Sedangkan menurut Undang-Undang No. 10 tahun 1998 (Perubahan Undang-undang Nomor 7 Tahun 1992 tentang Perbankan) pengertian Bank adalah badan usaha yang menghimpun dana dari masyarakat dalam 
bentuk simpanan, dan menyalurkannya kepada masyarakat dalam bentuk kredit dan bentukbentuk lainnya dalam rangka meningkatkan taraf hidup rakyat banyak. Dalam Pasal 1 ayat 3 Undang-Undang Nomor 10 Tahun 1998 menyebutkan bahwa Bank Umum adalah bank yang melaksanakan kegiatan usahanya secara konvensional dan/atau berdasarkan prinsip syariah yang dalam kegiatannya memberikan jasa dalam lalu lintas pembayaran.

Bank didefinisikan oleh Ratnasari (2015) merupakan perusahaan yang bergerak dalam bidang keuangan, artinya aktivitas perbankan selau berkaitan dalam bidang keuangan,sehingga berbicara mengenai bank tidak terlepas darimasalah keuangan.Bank adalah perusahaan yang beroperasi dalam bidang keuangan, yang berartiaktifitas perbankan berkaitan dalam bidang keuangan. Menurut Taswan (2010) bank merupakan lembaga perusahaann yang aktivitasnyamencakupmenghimpun dana berupa giro, deposito tabungan dan simpanan yang lain dari pihak yang kelebihan dana (surplus spending unit) melalui penjualan jasa keuangan yang pada gilirannya dapat meningkatkan kesejahteraan orang banyak. Pasal 2 Undang-Undang Nomor 10 Tahun 1998 tentang Perubahan Atas Undang-Undang Nomor 7 Tahun 1992 tentang Perbankan disebutkan bahwa perbankan Indonesia dalam melakukan usahanya berasaskan demokrasi ekonomi dengan menggunakan prinsip kehatihatian. Kemudian yang dimaksud dengan demokrasi ekonomi adalah demokrasi ekonomi berdasarkan Pancasila dan Undang-Undang
Dasar 1945. Demokrasi ekonomi ini tersimpul dalam Pasal 33 Undang-Undang Dasar 1945, yaitu perekonomian disusun sebagai usaha bersama berdasarkan asas kekeluargaan (Imaniyati, 2010). Pasal 3 Undang-Undang Nomor 10 Tahun 1998 tentang Perubahan Atas Undang-Undang Nomor 7 Tahun 1992 tentang Perbankan. Di Indonesia ini, lembaga perbankan memiliki misi dan fungsi sebagai agen pembangunan (agent of development). Menurut Pasal 4 Undang-Undang 10 Tahun 1998 tentang Perubahan Atas Undang-Undang Nomor 7 Tahun 1992 tentang Perbankan, perbankan Indonesia bertujuan menunjang pelaksanaan pembangunan nasional dalam rangka meningkatkan pemerataan, pertumbuhan ekonomi, dan stabilitas nasional ke arah peningkatan kesejahteraan rakyat banyak.

Menurut Kasmir (2011), jenis-jenis bank berdasarkan kepemilikannya dibedakan menjadi dua yaitu:

1. Bank milik pemerintah yaitu bank yang seluruh atau sebagian modalnya dan akte pendiriannya didirikan oleh pemerintah.

2. Bank milik swasta yaitu bank yang seluruh atau sebagian modalnya dan akte pendiriannya didirikan oleh swasta.

\section{Modal Kerja, Aset, Hutang, Pendapatan} dan Laba serta Saham

Menurut Fahmi (2012) modal kerja adalah investasi sebuah perusahaan pada aktiva-aktiva jangka pendek-kas, persediaan dan piutang. Modal kerja merupakan suatau ukuran dari likuiditas perusahaan. Menurut Hanafi (2013), aset adalah manfaat ekonomis 
yang akan diterima pada masa mendatang, atau akan dikuasai oleh perusahaan sebagai hasil dari transaksi atau kejadian. Sedangkan menurut Martani (2012), aset adalah sebagai sumber daya yang dikuasai oleh entitas sebagai akibat dari peristiwa masa lalu dan dari mana manfaat ekonomi di masa depan diharapkan akan diperoleh. Menurut Munawir (2013) hutang adalah semua kewajiban keuangan perusahaan kepada pihak lain yang belum terpenuhi, dimana hutang ini merupakan sumber dana atau modal perusahaan yang berasal dari kreditor. Menurut Sumarso (2009) pendapatan adalah adalah aliran masuk aktiva atau pengurangan utang yang diperoleh dari hasil penyerahan barang atau jasa kepada para pelanggan. Sedangkan Marbun (2013) menyatakan bahwa pendapatan adalah uang yang diterima oleh perorangan, perusahaan dan organisasi lain dalam bentuk upah, gaji, sewa, bunga, komisi, ongkos dan laba.

Menurut Darmadji dan Fakhrudin (2011) saham (stock) adalah sebagai tanda penyertaan atau pemilikan atau badan dalam suatu perusahaan atau perseroan terbatas. Saham berwujud selembar kertas yang menerangkan bahwa pemilik kertas tersebut adalah pemilik perusahaan yang menerbitkan surat berharga tersebut. Sedangkan Husnan (2005) saham adalah secarik kertas yang menunjukkan hak pemodal yaitu pihak yangmemiliki kertas tersebut untuk memperoleh bagian dari prospek atau kekayaaan organisasi yang menerbitkan sekuritas tersebut, dan berbagai kondisis yang memungkinkan pemodal tersebut menjalankan haknya.

\section{Financial Distress}

Financial distress merupakan suatu kondisi perusahaan yang mengalami illikuid akan tetapi masih dalam keadaan solven. Menurut Hanafi (2013), financial distress dapat digambarkan dari dua titik ekstrem yaitu kesulitan likuiditas jangka pendek sampai insolvabel. Kesulitan keuangan jangka pendek biasanya bersifat jangka pendek, tetapi bisa berkembang menjadi parah. Indikator kesulitan keuangan dapat dilihat dari analisis aliran kas, analisis strategi perusahaan, dan laporan keuangan perusahaan. Menurut Fahmi (2012) mendefinisikan financial distress sebagai tahap penurunan kondisi keuangan yang terjadi sebelum terjadinya kebangkrutan ataupun likuidasi. Financial distress dimulai dengan ketidakmampuan memenuhi kewajibankewajibannya, terutama kewajiban yang bersifat jangka pendek termasuk kewajiban likuiditas, dan juga termasuk kewajiban dalam kategori solvabilitas. Menurut Karina (2014), kebangkrutan (bankcruptcy) merupakan kondisi dimana perusahaan tidak mampu lagi untuk melunasi kewajibannya". Kondisi ini biasanya tidak muncul begitu saja di perusahaan, ada indikasi awal dari perusahaan tersebut yang biasanya dapat dikenali lebih dini kalau laporan keuangan dianalisis secara lebih cermat dengan suatu cara tertentu. Menurut Prihadi (2011), bankcruptcy adalah kondisi dimana perusahaan tidak mampu lagi untuk melunasi kewajibannya. Kondisi ini biasanya tidak muncul begitu saja di 
perusahaan, ada indikasi awal dari perusahaan tersebut yang biasanya dapat dikenal lebih dini kalau laporan keuangan dianalisis secara lebih cermat dengan suatu cara tertentu.

Weston \& Copeland dalam penelitian oleh Tambunan (2015) yaitu:

1. Kegagalan Ekonomi (Economic Distressed)

Kegagalan dalam arti ekonomis bahwa pendapatan perusahaan tidak mampu lagi menutupi biayanya, yang berarti bahwa tingkat labanya lebih kecil daripada biaya modalnya.

2. Kegagalan Keuangan (Financial Distressed)

Insolvensi memiliki dua bentuk yakni default teknis yang terjadi bila suatu perusahaan gagal memenuhi salah satu atau lebih kondisi di dalam ketentuan hutangnya, seperti rasio aktiva lancar dengan hutang lancar ditetapkan, serta kegagalan keuangan atau ketidakmampuan teknik (technical insolvency) yang terjadi apabila perusahaan tidak mampu memenuhi kewajibannya pada waktu yang ditentukan.

Terdapat berbagai metode dalam memprediksi kebangkrutan perusahaan. Metode tersebut berdasarkan penelitianpenelitian terdahulu terdapat metode Altman Z-Score, metode Springate dan Grover GScore.

\section{Kerangka berpikir}

Laporan Keuangan Perusahaan Perbankan (BRI, BNI, Bank Mandiri dan BTN) tahun 2015-2019

Analisis Prediksi Kebangkrutan Perusahaan untuk memperoleh peringatan awal kebangkrutan

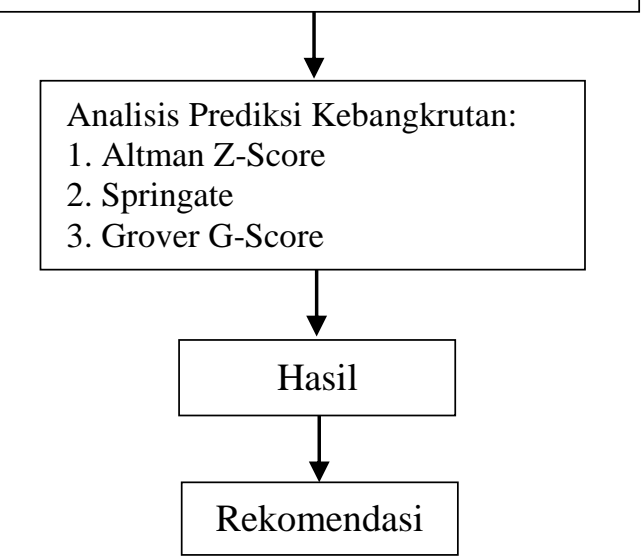

\section{Gambar 1 : Kerangka Berpikir}

\section{METODE PENELITIAN}

Objek penelitian ini adalah Bank BUMN yang terdaftar di Bursa Efek Indonesia, dengan focus penelitian adalah menganalisis potensi kebangkrutan pada objek penelitian tersebut. Penelitian ini dilakukan Selama 6 bulan waktu, yaitu dari bulan Maret 2020 sampai dengan September 2020.

Polupasi penelitian ini adalah seluruh bank BUMN yang terdaftar pada Bursa Efek Indonesia, yaitu sebanyak 4 perusahaan Bank BUMN, yaitu Bank BRI, Bank BNI, Bank Mandiri dan Bank BTN. Pada penelitian ini menggunakan sampel jenuh, dimana seluruh anggota populasi dijadikan sampel pada penelitian ini. Adapun data yang dianalisis adalah data sekunder berupa laporan keuangan perusahaan bank BUMN yang terdaftar di Bursa efek Indonesia, Periode 2015 - 2019. 


\section{Metode Analisis Data}

Tehnik analisis data pada penelitian ini menggunakan 3 model prediksi yang masingmasing memiliki perbedaan dalam perhitungan. Ketiga model tersebut dapat dilihat sebagai berikut.

\section{Altman Z-Score}

Altman menemukan lima jenis ratio keuangan yang dapat dikombinasikan untuk melihat perbedaan antara perusahaan yang bangkrut dan yang tidak bangkrut. Z-Score Altman untuk perusahaan perbankan yang telah go public ditentukan dengan menggunakan rumus sebagai berikut (Fahmi, 2012):

Z-Score $=1,2 \mathrm{X} 1+1,4 \mathrm{X} 2+3,3 \mathrm{X} 3+0,6 \mathrm{X} 4$ $+1,0 \times 5$

$$
\begin{aligned}
\mathrm{X} 1= & \text { Working Capital to Total Assets } \\
& \text { (Modal Kerja/Total Aset) } \\
\mathrm{X} 2= & \text { Retained Earning to Total Assets } \\
& \text { (Laba Ditahan/Total Aset) } \\
\mathrm{X} 3= & \text { Earning Before Interest and Taxes } \\
& (\text { EBIT) to Total Assets (Pendapatan }
\end{aligned}
$$
Sebelum Dikurangi Biaya Bunga/Total Aset)

X4 = Market Value of Equity to Book Value of Total Liabilities (Harga Pasar Saham Dibursa/Nilai Total Utang)

$\mathrm{X} 5=$ Sales to Total Assets (Penjualan/Total Aset)

Dengan kriteria penilaian sebagai berikut:

1. Z-Score > 2,99 dikategorikan sebagai perusahaan yang sangat sehat sehingga tidak mengalami kesulitan keuangan.
2. 1,81 $<$ Z-Score $<2,99$ berada di daerah abu-abu sehingga dikategorikan sebagai perusahaan yang memiliki kesulitan keuangan, namun kemungkinan terselamatkan dan kemungkinan bangkrut sama besarnya tergantung dari keputusan kebijaksanaan manajemen perusahaan sebagai pengambil keputusan.

3. Z-Score $<1,81$ dikategorikan sebagai perusahaan yang memiliki kesulitan keuangan yang sangat besar dan beresiko tinggi sehingga kemungkinan bangkrutnya sangat besar.

\section{Springate}

Model prediksi kebangkrutan yang dikenal sebagai model Springate ini menggunakan 4 rasio keuangan yang dipilih berdasarkan rasio-rasio keuangan dalam berbagai literatur. Model ini memiliki rumus sebagai berikut: (Prihanthini dan Maria, 2013:422)

$\mathrm{S}$-score $=1,03 \mathrm{~A}+3,07 \mathrm{~B}+0,66 \mathrm{C}+0,4 \mathrm{D}$

Keterangan:

A $=$ Working Capital/Total Asset (modal kerja/total aset)

$\mathrm{B}=$ Net Profit before Interest and Taxes/Total Asset (laba sebelum pajak dan bunga/total aset)

$\mathrm{C}=$ Net Profit before Taxes/Current Liabilities (laba sebelum pajak/hutang lancar)

$\mathrm{D}=$ Sales $/$ Total Asset (penjualan/total aset) Model Springate ini mengklasifikasikan perusahaan dengan skor $\mathrm{S}$ $>0,862$ merupakan perusahaan yang tidak berpotensi bangkrut, sebaliknya jika 
perusahaan memiliki skor $\mathrm{S}<0,862$ diklasifikasikan sebagai perusahaan yang tidak sehat dan berpotensi bangkrut.

\section{Grover G-Score}

Model Grover menghasilkan fungsi sebagai berikut: (Prihanthini dan Maria, 2013:420).

$\mathrm{G}$-Score $=1,650 \mathrm{X} 1+3,404 \mathrm{X} 3-0,016 \mathrm{ROA}+$ 0,057

Keterangan:

$\mathrm{X} 1=$ Working Capital/Total Assets

$\mathrm{X} 3$ =Earnings before Interest and Taxes/Total Assets

ROA = Net Income/Total Assets

Model Grover mengkategorikan perusahaan dalam keadaan bangkrut dengan skor kurang atau sama dengan $-0,02(\mathrm{G} \leq-0,02)$, sedangkan nilai untuk perusahaan yang dikategorikan dalam keadaan tidak bangkrut adalah lebih atau sama dengan $0,01(\mathrm{G} \geq 0,01)$.

\section{HASIL DAN PEMBAHASAN}

Analisis financial distres dalam memprediksi kebangkrutan pada perusahaan perbanakan dan dalam penelitian ini terdiri dari Bank Rakyat Indonesia, Bank Negara Indonesia, Bank Mandiri dan Bank Tabungan Negara. Finansial distres berdasarkan hasil perhitungan dengan menggunakan metode Altman Z Score secara keseluruhan berpotensi bangkrut, sementara dengan metode Springate semua perusahaan perbankan tidak berpotensi bangkrut serta sama halnya dengan menggunakan metode Grover.

Financial distres dengan menggunakan metode altman Z Score menggunakan lima rasio seperti untuk $\mathrm{X}_{1}$ membandingkan modal kerja denggan total aset, $\mathrm{X}_{2}$ laba ditahan dengan total aset, $X_{3}$ pendapatan sebelum dikurangi bunga dan pajak dengan total aset, X4 harga pasar saham dengan nilai total hutang dan X5 penjualan atau pendapatan dengan nilai total utang. Hasil perhitungan dengan metode Altman Z Score sebagai berikut.

Tabel 2

Financial Distress Dengan Metode Altman Z Score pada Bank BUMN Yang Terdaftar di BEI Tahun 2015-2019

\begin{tabular}{|l|l|l|l|}
\hline No & Bank & Z Score & \multicolumn{1}{|c|}{ Kriteria } \\
\hline 1 & BRI & 1,58 & Berpotensi bangkrut \\
\hline & & 1,55 & Berpotensi bangkrut \\
\hline & & 1,54 & Berpotensi bangkrut \\
\hline & & 1,53 & Berpotensi bangkrut \\
\hline & & 1,53 & Berpotensi bangkrut \\
\hline 2 & BNI & 1,43 & Berpotensi bangkrut \\
\hline & & 1,43 & Berpotensi bangkrut \\
\hline & & 1,43 & Berpotensi bangkrut \\
\hline & & 1,43 & Berpotensi bangkrut \\
\hline & & 1,44 & Berpotensi bangkrut \\
\hline 3 & Mandiri & 1,78 & Berpotensi bangkrut \\
\hline & & 1,71 & Berpotensi bangkrut \\
\hline & & 1,71 & Berpotensi bangkrut \\
\hline & & 1,71 & Berpotensi bangkrut \\
\hline & & 1,88 & Grey Area \\
\hline 4 & BTN & 1,47 & Berpotensi bangkrut \\
\hline & & 1,45 & Berpotensi bangkrut \\
\hline & & 1,44 & Berpotensi bangkrut \\
\hline & & 1,42 & Berpotensi bangkrut \\
\hline & & 1,43 & Berpotensi bangkrut \\
\hline
\end{tabular}

Sumber: Data Primer, diolah (2020)

Berdasarkan tabel 2 dapat diketahui hasil perhitungan dengan menggunakan model dari Altman Z Score secara keseluruhan, dari Bank Rakyat Indonesia, Bank Negara Indonesia dan Bank Mandiri dan Bank Tabungan Negara. Hasil hitung semua berada 
pada Z-Score $<1,81$ dikategorikan sebagai perusahaan yang memiliki kesulitan keuangan yang sangat besar dan beresiko tinggi sehingga kemungkinan bangkrutnya sangat besar, hal tersebut dikarenakan oleh setiap rasio dari model ini menghasilkan sangat kecil rasio sehingga pada saat dijumlah hasilnya menjadi kecil.

Financial distres dengan menggunakan metode Springate menggunakan empat rasio seperti untuk A membandingkan modal kerja denggan total aset, B laba sebelum pajak dan bunga dengan total aset, C laba sebelum dikurangi bunga dan pajak dengan hutang lancar, D penjualan dengan total aset. Hasil perhitungan dengan metode Springate sebagai berikut.

\section{Tabel 3}

Financial Distress Dengan Metode Springate pada Bank BUMN Yang Terdaftar di BEI

Tahun 2015-2019

\begin{tabular}{|c|l|l|l|}
\hline No & Bank & S Score & Kriteria \\
\hline 1 & BRI & 5,33 & Tidak Berpotensi bangkrut \\
\hline & & 5,49 & Tidak Berpotensi bangkrut \\
\hline & & 4,83 & Tidak Berpotensi bangkrut \\
\hline & & 4,38 & Tidak Berpotensi bangkrut \\
\hline 2 & BNI & 4,91 & Tidak Berpotensi bangkrut \\
\hline & & 3,96 & Tidak Berpotensi bangkrut \\
\hline & & 3,41 & Tidak Berpotensi bangkrut \\
\hline & & 4,23 & Tidak Berpotensi bangkrut \\
\hline & & 3,50 & Tidak Berpotensi bangkrut \\
\hline 3 & Mandiri & 52,26 & Tidak Berpotensi bangkrut \\
\hline & & 42,06 & Tidak Berpotensi bangkrut \\
\hline & & 27,28 & Tidak Berpotensi bangkrut \\
\hline & & 27,28 & Tidak Berpotensi bangkrut \\
\hline & & 44,08 & Tidak Berpotensi bangkrut \\
\hline 4 & BTN & 1,95 & Tidak Berpotensi bangkrut \\
\hline & & 2,13 & Tidak Berpotensi bangkrut \\
\hline & & 1,98 & Tidak Berpotensi bangkrut \\
\hline & & 2,11 & Tidak Berpotensi bangkrut \\
\hline
\end{tabular}

\begin{tabular}{|l|l|}
\hline 2,43 & Tidak Berpotensi bangkrut \\
\hline
\end{tabular}

Sumber: Data Primer, diolah (2020)

Berdasarkan tabel 3 dapat diketahui hasil perhitungan dengan menggunakan model dari Springate secara keseluruhan, dari Bank Rakyat Indonesia, Bank Negara Indonesia dan Bank Mandiri dan Bank Tabungan Negara. Hasil hitung semua berada pada skor $\mathrm{S}>0,862$ merupakan perusahaan yang tidak berpotensi bangkrut.

Financial distres dengan menggunakan metode Grover menggunakan tiga rasio seperti untuk $\mathrm{X} 1$ membandingkan modal kerja denggan total aset, X3 laba sebelum pajak dan bunga dengan total aset, ROA laba bersih dengan total aset, serta 0,057 ketetapan dari model ini. Hasil perhitungan dengan metode Grover sebagai berikut.

\section{Tabel 4}

Financial Distress Dengan Metode Gorver pada Bank BUMN Yang Terdaftar di BEI Tahun 2015-2019

\begin{tabular}{|c|c|c|c|}
\hline No & Bank & G Score & Kriteria \\
\hline \multirow[t]{5}{*}{1} & BRI & 1,79 & Tidak Berpotensi bangkrut \\
\hline & & 1,75 & Tidak Berpotensi bangkrut \\
\hline & & 1,74 & Tidak Berpotensi bangkrut \\
\hline & & 1,75 & Tidak Berpotensi bangkrut \\
\hline & & 1,75 & Tidak Berpotensi bangkrut \\
\hline \multirow[t]{5}{*}{2} & $\mathrm{BNI}$ & 1,70 & Tidak Berpotensi bangkrut \\
\hline & & 1,71 & Tidak Berpotensi bangkrut \\
\hline & & 1,71 & Tidak Berpotensi bangkrut \\
\hline & & 1,71 & Tidak Berpotensi bangkrut \\
\hline & & 1,71 & Tidak Berpotensi bangkrut \\
\hline \multirow[t]{5}{*}{3} & Mandiri & 1,99 & Tidak Berpotensi bangkrut \\
\hline & & 1,94 & Tidak Berpotensi bangkrut \\
\hline & & 1,96 & Tidak Berpotensi bangkrut \\
\hline & & 1,96 & Tidak Berpotensi bangkrut \\
\hline & & 2,15 & Tidak Berpotensi bangkrut \\
\hline \multirow[t]{2}{*}{4} & BTN & 1,73 & Tidak Berpotensi bangkrut \\
\hline & & 1,71 & Tidak Berpotensi bangkrut \\
\hline
\end{tabular}




\begin{tabular}{|l|l|l|l|}
\hline & & 1,71 & Tidak Berpotensi bangkrut \\
\hline & & 1,71 & Tidak Berpotensi bangkrut \\
\hline & & 1,71 & Tidak Berpotensi bangkrut \\
\hline
\end{tabular}

Sumber: Data Primer, diolah (2020)

Berdasarkan tabel 4 dapat diketahui hasil perhitungan dengan menggunakan model dari grover secara keseluruhan, dari Bank Rakyat Indonesia, Bank Negara Indonesia dan Bank Mandiri dan Bank Tabungan Negara. Hasil hitung dengan nilai-nilai untuk perusahaan yang dikategorikan dalam keadaan tidak bangkrut adalah lebih atau sama dengan $0,01(\mathrm{G} \geq 0,01)$.

\section{Hasil perhitungan Altman Z Score} yang menunjukkan adanya potesin kebangkrutan karena setiap perbandingan yang digunakan pada model secara umum dengan menggunakan total aktiva, dimana total aktiva umumnya nilai lebih besar bila dibandingkan dengan modal kerja, laba ditahan, laba sebelum pajak dan bunga dan juga pendapatan, demikian juga dengan nilai masing-masing $X$ yang kecil bila dibandingkan dengan model springate dan Grover. Untuk itu model Altman $\mathrm{Z}$ Score lebih baik digunakan dan menunjukkan kondisi keuangan perusahaan perbankan.. Hasil penelitian ini sejalan dengan penelitian Korry, et. al (2019) bahwa semua Bank BUMN berada pada kondisi grey area periode tahun 2014-2017 karena nilai Z-Score yang diperoleh berada diantara 1,1 dan 2,6.

\section{KESIMPULAN DAN SARAN}

Berdasarkan hasil hitung dengan model Alman Z Score diperoleh pada Z-Score $<1,81$ dikategorikan sebagai perusahaan yang memiliki kesulitan keuangan yang sangat besar dan beresiko tinggi sehingga kemungkinan bangkrutnya sangat besar. Sementara erdasarkan hasil hitung dengna model springate diperoleh $\mathrm{S}>0,862$ merupakan perusahaan yang tidak berpotensi bangkrut, dan berikutnya, berdasarkan hasil hitung dengan model Grover diperoleh $\mathrm{G} \geq 0,01$ merupakan perusahaan yang tidak berpotensi bangkrut.

Berdasarkan ketiga model yang digunakan maka yang paling baik dalam memprediksi kebangkrutan perusahaan (financial distress) adalah model Altman Z-Score karena model ini memiliki banyak rasio untuk mengukur kondisi keuangan perusahaan perbankan sehingga pihak perusahaan perbankan dapat berjaga-jaga atas kondisi kesulitan keuangannya

Berdasarkan model altman yang seluruhnya mengalami potensi kebangkrutan, sebaiknya manajemen perusahaan melakukan evaluasi dan lebih berhati-hati dalam mengelola keuangan perusahaan. Selain mengoptimalkan kinerja keuangan juga sebaiknya selalu mengontrol risiko baik internal maupun eksternal yang dapat mempengaruhi likuiditas perusahaan dan menyebabkan financial distress bahkan kebangkrutan. Sementara untuk investor, sebaiknya selalu memperhatikan kondisi perusahaan perbankan berdasarkan rasio-rasio keuangan, sebelum melakukan investasi, sehingga mengetahui kondisi perusahaan, apakah kondisi keuangan perusahaan baik atau buruk. 


\section{REFERENSI}

Anoraga. Panji. 2006. Pengantar Bisnis. Jakarta: Rineka Cipta.

Darmadji, Tjiptono dan Fakhruddin. 2011.

Pasar Modal di Indonesia. Jakarta:

Salemba Empat.

Diratama, Ichsan. 2017. Analisis Prediksi

Kebangkrutan pada Perusahaan

Pertambangan yang terdaftar di Bursa

Efek Indonesia tahun 2014-2016.

Jurnal Akuntansi dan Bisnis. Vol 1.

No. 2 Hal 1-10.

Effendi, Ria. 2018. Analisis Prediksi

Kebangkrutan dengan Metode Altman,

Springate, Zmijewski, Fster dan

Grover pada Emiten jasaa transportasi.

Parsiomia. Vol 4 No. 3 Hal: 307-319.

Fahmi. Irham. 2012. Teori Pengambilan

Keputusan. Bandung: Alfabeta.

Ghosn, Fadi. 2019. Predicting Financial

Distress in Lebanese Non Listed

Banks. International Journal of

Sciences Basic and Applied Research

(IJSBAR). Vol 47. No. 1. Hal: 57-67.

Hanafi, Mamduh. 2013. Analisis Laporan

Keuangan. Yogyakarta: AMP YKPN.

Husnan, Suad. 2005. Dasar-dasar

Manajemen Keuangan. Yogyakarta:

UPP STIM YKPN.

Imaniyati, Neni Sri. 2010. Pengantar Hukum

Perbankan Indonesia. Bandung:

Refika Aditama.

Karina, Dewi Mutiara. 2013. Analisis Faktor -

Faktor Yang Mempengaruhi Ketepatan

Waktu Dan Audit Delay Penyampaian

Laporan Keuangan. Skripsi. Fakultas
Ekonomi Dan Bisnis Universitas

Diponegoro. Semarang.

Kasmir, 2011, Manajemen Perbankan, Jakarta: PT. RajaGrafindo Persada. , 2015, Analisa Laporan Keuangan, Jakarta: PT. RajaGrafindo Persada.

Marbun, B.N. 2013. Kamus Manajemen. Jakarta: Pustaka Sinar Harapan.

Martani, Dwi. 2012. Akuntansi Keuangan

Menengah. Jakarta: Salemba Empat.

Munawir. 2013. Analisa Laporan Keuangan.

Yogyakarta: Liberty.

Platt H.D. dan Platt M.B. 2002. Predicting

Corporate Financial Distress:

Reflections on Choice-Based Sample

Bias. Journal of Economics and

Finance, Vol.26 N.2, Hal 184-199.

Prihadi, Toto. 2011. Analisis Laporan

Keuangan Teori dan Aplikasi.

Jakarta: Penerbit PPM.

Prihantini, N.M.E. Dwi dan Maria. M.R. Sari. 2013. Prediksi Kebangkrutan Perusahaan dengan Model Grover, Altman Z Score dan Zmijewski pada Perusahaan Food and Beverage di Bursaa Efek Indonesia. Ejournal Akunansi. Vol 5. No 2. Hal: 417-435. Ratnasari, Sri Langgeng. 2015. Bank dan Lembaga Keuangan Lainnya. Jakarta: Kencana Media Group.

Rahayu, Sri. 2016. Pengaruh Opini Audit Tahun Sebelumnya, Pertumbuhan Perusahaan, Leverage dan Reputasi Auditor Terhadap Penerimaan Opini Going Concern. Proceeding PESAT 
(Psikologi, Ekonomi, Sastra, Arsitektur \& Sipil), Hal: 98-104.

Rahmat, Aprianto. 2005. Keputusan Investasi, Keputusan Pendanaan, Kebijakan Deviden dan Struktur Kepemilikan terhadap Nilai (Studi pada Perusahaan Manufaktur yang terdaftar di BEI tahun 2008-2010). Jurnal Ekonomi dan Bisnis. Vol 15. No. 1 Semarang: Universitas Islam Sultan Agung.

Sugiyono, 2011, Metode Penelitian Bisnis, Bandung: Alfabeta.

\section{— 2017, Metode Penelitian \\ Kuantitatif, Kualitatif dan R\&D, \\ Bandung: Alfabeta}

Stice, James D. Stice, Earl K dan Skousen, K.

Fred. 2009. Akuntansi Keuangan.

Jakarta: Salemba Empat.

Tambunan, Rafles W, Dwiatmanto dan Endang

WI. 2015. Analisis Prediksi

Kebangkrutan Perusahaan dengan

Menggunakan Metode Altman (Zscore) (Studi pada Subsektor Rokok yang Listing dan Perusahaan Delisting di Bursa Efek Indonesia) tahun 20092013 . Jurnal Administrasi Bisnis (JAB). Vol 2. No 1 Hal: 1-11.

Tambunan. Andy P. 2015. Menilai Harga

Wajar Saham. Jakarta: PT. Elex Media Komputindo.

Taswan. 2010. Manajemen Perbankan

(Konsep, Teknik dan Aplikasi).

Yogyakarta: UPP STIM YKPN.

Undang-undang Nomor 10 Tahun 1998,

Tentang Perbankan, Jakarta.
Weston. J. Fred dan Cofeland, Thomas.E. 2010. Manajemen Keuangan. Jakarta: Binarupa.

Wulandari, Fitria. Burhanudin dan Widayanti Rochmi. 2017. Analisis Prediksi Kebangkrutan Menggunakan Mete Altman (Z-Score) pada Perusahaan Farmasi (Studi Kasus pada Perusahaan yang Terdaftar di Bursa Efek Indonesia Tahun 20111-2015). Jurnal Manajemen dan Bisnis. Vol 2. No. 1 Hal: 15-27

www.idx.co.id, id-id / beranda / perusahaan tercatat / laporan keuangan dan tahunan. aspx, diunduh tanggal 13 April 2017

Yulia, Efni. 2015. Pengaruh Kesempatan Investasi, Leverage Terhadap Kebijakan Deviden Dan Nilai Perusahaan Pada Perusahaan Manufaktur Yang Terdaftar Di Bursa Efek Indonesia. Jurnal Tepak Manajemen Bisnis, Vol. VII No. 3

Zulkarnain, Muhammad. 2020. Pengaruh Total Aktiva dan Pendapatan Terhadap Laba Bersih (Studi Perusahaan Perbankan LQ 45 BEI). Journal of Applied Business Administration. Vol. 20. No. 1.

Korry, I Komang Try Satriawan, et.al (2019) Analisis Prediksi Kebangkrutan Berdasarkan Metode Altman, Z-Score (Studi pada Kasus pada Bank BUMN yang terdaftar di BEI). Buletin Studi Ekonomi. Vol. 24 No. 2. 